\title{
Evaluation of the Causes of Flexible Pavement Failure; Case Study of Enugu/Port-Harcourt Expressway
}

\author{
E. C. Amanamba ${ }^{1, *}$, C. Chioke $^{2}$, A. C. Ekeleme $^{3}$ \\ 1,3 Department of Civil Engineering, Abia State University, Uturu, Abia State, NIGERIA \\ ${ }^{2}$ Department of Building and Woodwork Technology Education, Federal College of Education (Technical), Umunze, Anambra State, NIGERIA
}

\begin{abstract}
This study examined the causes of flexible pavement failure, taking the Enugu/Port-Harcourt expressway as a case study; to understand possible peculiarities. Chainages 101+400 and 125+925 were the most critical, having potholes of 500mm in depth; hence, soil samples were taken from these spots. The following tests were conducted: Particle size distribution, Atterberg limits, Permeability, Compaction, and California Bearing Ratio (CBR). The results obtained showed evidence of presence of clay in the subgrade; hence, concluding that the failure was mainly caused by poor soil material. From visual condition survey, it was noted that there were no drainages even at the critical paths of the alignment, and there was a significant proportion of Heavy Goods Vehicles (HGVs) which may not have been adequately considered during design.
\end{abstract}

Keywords: flexible pavement, pavement failure, clay, subgrade, soil test

\subsection{INTRODUCTION}

The volume of infrastructure available to citizens is certainly an index for measuring national development. In Nigeria, several billions are budgeted for road construction annually. Ironically, as more roads are seemingly built, several more deteriorate; in fact, along several routes, while the contractor is still on site, some sections of the alignment under construction would show traces of imminent failure. The magnitude and frequency of pavement failure in Nigeria is alarming, as virtually all major highways are either being rehabilitated or in a state of failure.

Road maintenance is an integral component of the entire process of highway construction and operation. Highway maintenance is essential as it helps preserve the highway in its original condition or nearly so; hence, financial savings as less money would be voted for these highways, promote road user experience, and help maintain the economy of the nation. Unfortunately, adequate maintenance is often neglected resulting in rapid deterioration of the roadway and eventual failure from both environmental and vehicular impacts.

There exist several researches on the causes of flexible pavement failure, some of the various factors have been categorized. Evidence suggests that the most common cause of flexible pavement failure is attributed to the pavement materials, especially the soil. [1,2] suggested that attention should be paid to mixture of highway materials, to forestall flexible pavement failures,

*Corresponding author (Tel: +234 (0) 803792 2088)

Email addresses: engr.namba@gmail.com (E. C. Amanamba), educhioke@gmail.com (C. Chioke),

chytony4real09@gmail.com (A. C. Ekeleme). similarly, $[3,4,5,6,7]$ blamed soil materials of inadequate strength for flexible pavement failures. According to [8], deterioration of flexible pavements is primarily caused by traffic loads exceeding the limits considered during the design of such roads. Studies by $[9,10,11]$ suggested that these frequent flexible pavement failures are certainly a function of poor design. Amongst the several potential causes of flexible pavement failure, $[7,12,13]$ concluded that poor drainage was the main culprit. Timely rehabilitation of flexible pavements, however, can save overall maintenance costs by over $50 \%$ [14].

This paper seeks to find justification to corroborate the findings of the several researchers who have examined the causes of flexible pavement failure: taking evidence from a different alignment.

\subsection{MATERIALS AND METHODS \\ $2.1 \quad$ Materials}

The road selected for this case study is the Enugu/Port-Harcourt expressway. The road is about $200 \mathrm{~km}$ in length, with the reference point commencing at 'Naira triangle' in Enugu state and terminating at 'Eleme junction' in Rivers state.

Disturbed soil samples were collected at two locations $(\mathrm{CH} \mathrm{101+400} \mathrm{and} \mathrm{CH} 125+925)$ along the route. These spots were the worst points of failure along the entire route; having absolute loss of pavement section. These samples were obtained at about 11:30hours on 10th August, 2012, and soil testing began almost immediately. The idea was to examine the subgrade soil, which would usually be at a depth of $650-750 \mathrm{~mm}$ from the wearing course. It was considered that since these two test spots had potholes of about $500 \mathrm{~mm}$ depth, there was no point having test pits which are beyond $500 \mathrm{~mm}$ depth. Hence, 
the samples were collected with a post-hole soil auger. A hole of $200 \mathrm{~mm}$ was first dug right on the traffic bearing lanes of the carriageway, then with a soil auger, disturbed samples were taken.

\subsection{Experimental Programme}

Firstly, visual condition survey was carried out along the entire alignment to categorise the nature of pavement failure. Chainages $101+400$ and $125+925$ were the most critical, having potholes of $500 \mathrm{~mm}$ in depth. Secondly, traffic survey was conducted to note the composition of vehicular traffic; the traffic survey was done for two days between the hours of 08:00 and 17:00, to capture fairly, the morning and evening peak. Thirdly, laboratory tests were conducted. The tests include: Particle size distribution, Atterberg limits, Permeability, Compaction, and California Bearing Ratio (CBR), following the methods adopted in a similar study [15]. All laboratory tests were conducted in accordance with BS1377 Methods of Test for Soils for Civil Engineering Purposes [16], and BS 6031 Codes of practice for earth works [17]. The soil classification was based on AASHTO system [18]. The sample from $\mathrm{CH} 125+925$ was labelled sample 1, and the sample from $\mathrm{CH} 101+400$ was labelled sample 2 .

\subsection{RESULTS AND DISCUSSION \\ 3.1 Particle Size Distribution}

$200 \mathrm{~g}$ of samples 1 and 2 were independently characterised following the particle size distribution. From table 1, the percentage passing sieve no. 200 $(0.075 \mathrm{~mm})$, for sample 1 is $46.5 \%$, and for sample 2 , the percentage passing sieve no. $200(0.075 \mathrm{~mm})$ is $44.0 \%$, as seen in table 2. From AASHTO classification, these percentages show that there is presence of A-7-6 materials [18]; this indicates the presence of clay in the subgrade.

Table 1: Sample 1 Particle Size Distribution

\begin{tabular}{llllll}
\hline $\begin{array}{l}\text { Sieve size } \\
(\mathbf{m m})\end{array}$ & $\begin{array}{l}\text { Mass } \\
\text { retained }(\mathbf{g})\end{array}$ & $\begin{array}{l}\text { Percentage } \\
\text { retained }(\boldsymbol{\%})\end{array}$ & $\begin{array}{l}\text { Cumulative } \\
\text { mass }(\mathbf{g})\end{array}$ & $\begin{array}{l}\text { Percentage cumulative } \\
\text { mass retained }(\%)\end{array}$ & $\begin{array}{l}\text { Percentage } \\
\text { passing }(\boldsymbol{\%})\end{array}$ \\
\hline $\mathbf{4 . 7 6 0}$ & 0.0 & 0.0 & 0.0 & 0.0 & 100.0 \\
$\mathbf{2 . 3 8 0}$ & 2.0 & 1.0 & 2.0 & 1.0 & 99.0 \\
$\mathbf{1 . 1 9 0}$ & 8.0 & 4.0 & 10.0 & 5.0 & 95.0 \\
$\mathbf{0 . 6 0 0}$ & 8.0 & 4.0 & 18.0 & 9.0 & 91.0 \\
$\mathbf{0 . 4 2 5}$ & 8.0 & 4.0 & 26.0 & 13.0 & 87.0 \\
$\mathbf{0 . 3 0 0}$ & 13.0 & 6.5 & 39.0 & 19.5 & 80.5 \\
$\mathbf{0 . 1 5 0}$ & 35.0 & 17.5 & 74.0 & 37.0 & 63.0 \\
$\mathbf{0 . 0 7 5}$ & 33.0 & 16.5 & 107.0 & 53.5 & 46.5 \\
Pan & 93.0 & 46.5 & 200.0 & 100.0 & 0.0 \\
\hline
\end{tabular}

Table 2: Sample 2 Particle Size Distribution

\begin{tabular}{llllll}
\hline $\begin{array}{l}\text { Sieve size } \\
(\mathbf{m m})\end{array}$ & $\begin{array}{l}\text { Mass } \\
\text { retained }(\mathbf{g})\end{array}$ & $\begin{array}{l}\text { Percentage } \\
\text { retained }(\%)\end{array}$ & $\begin{array}{l}\text { Cumulative } \\
\text { mass }(\mathbf{g})\end{array}$ & $\begin{array}{l}\text { Percentage cumulative } \\
\text { mass retained }(\%)\end{array}$ & $\begin{array}{l}\text { Percentage } \\
\text { passing }(\%)\end{array}$ \\
\hline $\mathbf{4 . 7 6 0}$ & 0.0 & 0.0 & 0.0 & 0.0 & 100.0 \\
$\mathbf{2 . 3 8 0}$ & 5.0 & 2.0 & 5.0 & 2.5 & 97.5 \\
$\mathbf{1 . 1 9 0}$ & 21.0 & 10.5 & 26.0 & 13.0 & 87.0 \\
$\mathbf{0 . 6 0 0}$ & 13.0 & 6.5 & 39.0 & 19.5 & 80.5 \\
$\mathbf{0 . 4 2 5}$ & 10.0 & 5.0 & 49.0 & 24.5 & 75.5 \\
$\mathbf{0 . 3 0 0}$ & 9.0 & 4.5 & 58.0 & 29.0 & 71.0 \\
$\mathbf{0 . 1 5 0}$ & 24.0 & 12.0 & 82.0 & 41.0 & 59.0 \\
$\mathbf{0 . 0 7 5}$ & 30.0 & 15.0 & 112.0 & 56.0 & 44.0 \\
$\mathbf{P a n}$ & 88.0 & 44.0 & 200.0 & 100.0 & 0.0 \\
\hline
\end{tabular}

\subsection{Atterberg Limit}

The Casagrande apparatus method was employed in the determination of the liquid limit of the two samples.
For sample 1, the liquid limit read off the plot obtained was $79.8 \%$, and for sample 2, the liquid limit read of the plot obtained was $85.2 \%$. The plastic limit values were 
thus: $43.7 \%$ for sample 1 , and $40.6 \%$ for sample 2 (see table 3 and table 4). From AASHTO classification, these percentages show that there is presence of A-7-6 materials

[18]; this indicates the presence of clay in the subgrade.

Table 3: Sample 1 Atterberg Limits

\begin{tabular}{lllllllll}
\hline & \multicolumn{3}{l}{ LIQUID LIMIT } & & \multicolumn{3}{l}{ PLASTIC LIMIT } \\
\hline Container Number & 1 & 2 & 3 & 4 & 5 & 6 & 7 & 8 \\
Number of blows & 12 & 19 & 28 & 38 & 49 & - & - & - \\
Weight of wet soil + container $(\mathbf{g})$ & 34.4 & 31.8 & 34.0 & 30.7 & 34.3 & 25.2 & 26.0 & 25.7 \\
Weight of dry soil + container $(\mathbf{g})$ & 26.1 & 24.6 & 26.1 & 24.2 & 26.1 & 22.6 & 23.0 & 22.6 \\
Weight of water $(\mathbf{g})$ & 8.3 & 7.2 & 7.9 & 6.5 & 8.2 & 2.9 & 3.0 & 3.1 \\
Weight of container $(\mathbf{g})$ & 16.1 & 15.7 & 16.1 & 15.9 & 16.1 & 15.9 & 16.1 & 15.6 \\
Weight of dry soil $(\mathbf{g})$ & 10.0 & 8.9 & 10.0 & 8.3 & 10.0 & 6.7 & 6.9 & 7.0 \\
Water content $(\%)$ & 83.0 & 80.9 & 79.0 & 78.3 & 82.0 & 43.3 & 43.5 & 44.3 \\
\hline
\end{tabular}

Table 4: Sample 2 Atterberg Limits

\begin{tabular}{lllllllllll}
\hline & \multicolumn{3}{c}{ LIQUID LIMIT } & & & \multicolumn{3}{l}{ PLASTIC LIMIT } \\
\hline Container Number & 1 & 2 & 3 & 4 & 5 & 6 & 7 & 8 \\
Number of blows & 12 & 20 & 27 & 38 & 49 & - & - & - \\
Weight of wet soil + container $(\mathbf{g})$ & 35 & 33.5 & 34.6 & 33.3 & 34.3 & 26.6 & 25.9 & 25.2 \\
Weight of dry soil + container $(\mathbf{g})$ & 26.1 & 25.2 & 26.1 & 25.4 & 26.1 & 23.4 & 23.1 & 22.5 \\
Weight of water $(\mathbf{g})$ & 8.9 & 8.3 & 8.5 & 7.9 & 8.2 & 3.2 & 2.8 & 2.7 \\
Weight of container $(\mathbf{g})$ & 16.1 & 15.7 & 16.1 & 15.9 & 16.1 & 15.9 & 16.1 & 15.6 \\
Weight of dry soil $(\mathbf{g})$ & 10.0 & 9.5 & 10.0 & 9.5 & 10.0 & 7.5 & 7.0 & 6.9 \\
Water content $(\boldsymbol{\%})$ & 89.0 & 87.9 & 85.0 & 83.2 & 82.0 & 42.7 & 40.0 & 39.1 \\
\hline
\end{tabular}

\subsection{Permeability Test}

The falling head method was adopted for the determination of the permeability value for both samples. For each of the samples, the experiment was run twice (as recorded in table 5 and table 6 ), so that the average would be taken as the substantive value. For sample 1, the average of the two values obtained was $8.03 \times 10^{-7}$, and for sample 2, the average of the two values obtained was $8.19 \times 10^{-7}$. These values obtained are indicative of clay, according to standard chart of permeability coefficient for various soil types [19].

Table 5: Sample 1 Permeability Tests

\begin{tabular}{llllllll}
\hline Run & $\begin{array}{l}\text { Initial } \\
\text { Head, } \mathbf{H}_{\mathbf{0}} \\
(\mathbf{c m})\end{array}$ & $\begin{array}{l}\text { Final } \\
\text { Head, } \mathbf{H}_{\mathbf{1}} \\
(\mathbf{c m})\end{array}$ & $\begin{array}{l}\text { Time } \\
(\mathbf{s e c})\end{array}$ & $\begin{array}{l}\text { Area of } \\
\text { burette, } \mathbf{A} \\
\left(\mathbf{c m}^{2}\right)\end{array}$ & $\begin{array}{l}\text { Area of } \\
\text { sample, } \mathbf{A} \\
\left(\mathbf{c m}^{2}\right)\end{array}$ & $\begin{array}{l}\text { Length of } \\
\text { sample, } \mathbf{L} \\
(\mathbf{c m})\end{array}$ & $\begin{array}{l}\text { Permeability, K } \\
(\mathbf{c m} / \mathbf{s e c})\end{array}$ \\
\hline $\mathbf{1}$ & 100 & 95 & 25200 & 1.33 & 23.76 & 7 & $7.97 \times 10^{-7}$ \\
$\mathbf{2}$ & 95 & 90 & 26400 & 1.33 & 23.76 & 7 & $8.08 \times 10^{-7}$ \\
\hline
\end{tabular}

Table 6: Sample 2 Permeability Tests

\begin{tabular}{llllllll}
\hline Run & $\begin{array}{l}\text { Initial } \\
\text { Head, } \mathbf{H}_{\mathbf{0}} \\
(\mathbf{c m})\end{array}$ & $\begin{array}{l}\text { Final } \\
\text { Head, } \mathbf{H}_{\mathbf{1}} \\
(\mathbf{c m})\end{array}$ & $\begin{array}{l}\text { Time } \\
(\mathbf{s e c})\end{array}$ & $\begin{array}{l}\text { Area of } \\
\text { burette, } \mathbf{A} \\
\left(\mathbf{c m}^{2}\right)\end{array}$ & $\begin{array}{l}\text { Area of } \\
\text { sample, } \mathbf{A} \\
\left(\mathbf{c m}^{2}\right)\end{array}$ & $\begin{array}{l}\text { Length of } \\
\text { sample, } \mathbf{L} \\
(\mathbf{c m})\end{array}$ & $\begin{array}{l}\text { Permeability, } \mathbf{K} \\
(\mathbf{c m} / \mathbf{s e c})\end{array}$ \\
\hline $\mathbf{1}$ & 100 & 95 & 23290 & 1.33 & 23.76 & 7 & $8.62 \times 10^{-7}$ \\
$\mathbf{2}$ & 95 & 90 & 27270 & 1.33 & 23.76 & 7 & $7.76 \times 10^{-7}$ \\
\hline
\end{tabular}




\subsection{California Bearing Ratio}

Table 7 shows that sample 1 had CBR value of $3.0 \%$, and the CBR value for sample 2 was taken to be $3.0 \%$ too (see table 8 ). The tests were conducted and adjusted with a ring factor of 4.72 . For soil material to be suitable for use as subgrade, it must have a minimum CBR value of 5\% [20]; hence, these soil samples are clearly unsuitable as subgrade.

Table 7: Sample 1 CBR Test

\begin{tabular}{lcccccccccccc}
\hline Pen. $(\mathbf{m m})$ & $\mathbf{0 . 5}$ & $\mathbf{1 . 0}$ & $\mathbf{1 . 5}$ & $\mathbf{2 . 0}$ & $\mathbf{2 . 5}$ & $\mathbf{3 . 0}$ & $\mathbf{3 . 5}$ & $\mathbf{4 . 0}$ & $\mathbf{4 . 5}$ & $\mathbf{5 . 0}$ & $\mathbf{5 . 5}$ & $\mathbf{6 . 0}$ \\
\hline Dial reading & 3.0 & 4.0 & 5.0 & 5.5 & 6.0 & 7.0 & 8.0 & 9.0 & 10.0 & 11.0 & 12.0 & 13.0 \\
Load (kN) & & & & & 0.283 & & & & & 0.519 & & \\
Dial reading & 4.0 & 5.0 & 7.0 & 8.0 & 10.0 & 11.0 & 12.0 & 13.0 & 14.0 & 15.0 & 16.0 & 17.0 \\
Load (kN) & & & & & 0.472 & & & & & 0.708 & \\
Average CBR values (\%) & & & & & 2.8 & & & & & 3.0 & \\
\hline
\end{tabular}

Table 8: Sample 2 CBR Test

\begin{tabular}{lcccccccccccc}
\hline Pen. $(\mathbf{m m})$ & $\mathbf{0 . 5}$ & $\mathbf{1 . 0}$ & $\mathbf{1 . 5}$ & $\mathbf{2 . 0}$ & $\mathbf{2 . 5}$ & $\mathbf{3 . 0}$ & $\mathbf{3 . 5}$ & $\mathbf{4 . 0}$ & $\mathbf{4 . 5}$ & $\mathbf{5 . 0}$ & $\mathbf{5 . 5}$ & $\mathbf{6 . 0}$ \\
\hline Dial reading & 1.0 & 2.0 & 3.0 & 4.0 & 5.0 & 6.0 & 8.0 & 9.0 & 10.0 & 12.0 & 13.0 & 14.0 \\
Load (kN) & & & & & 0.236 & & & & & 0.566 & \\
Dial reading & 2.0 & 5.0 & 7.0 & 9.0 & 11.0 & 12.0 & 12.5 & 13.0 & 13.5 & 14.0 & 15.0 & 16.0 \\
Load (kN) & & & & & 0.519 & & & & & 0.661 & & \\
Average CBR values (\%) & & & & & 2.8 & & & & & 3.0 & & \\
\hline
\end{tabular}

\subsection{Compaction Test}

The compaction test experiment was conducted following the specifications of the modified proctor test: 25 blows on each of 5 layers with $4.5 \mathrm{~kg}$ rammer, $45 \mathrm{~cm}$ drop, cylinder diameter of $15.24 \mathrm{~cm}$, height of $12.7 \mathrm{~cm}$, and volume of $2,315 \mathrm{~cm}^{3}$.
For sample 1, the optimum moisture content required to obtained maximum dry density of $1.92 \mathrm{~g} / \mathrm{cm}^{3}$ is $18.2 \%$ (see table 9); for sample 2, the optimum moisture content $18.1 \%$ was achieved at dry density of $1.91 \mathrm{~g} / \mathrm{cm}^{3}$ (see table 10). According to [21], soils with optimum moisture content range between $18-20 \%$ are cohesionless soils.

Table 9: Sample 1 Compaction Test

\begin{tabular}{llllll}
\hline Vol. of water added & $\mathbf{3 6 0}$ & $\mathbf{1 2 0}$ & $\mathbf{1 2 0}$ & $\mathbf{1 2 0}$ & $\mathbf{1 2 0}$ \\
\hline Weight of cylinder + soil (g) & 8090 & 8414 & 8553 & 8307 & 8145 \\
Weight of cylinder $(\mathbf{g})$ & 4108 & 4108 & 4108 & 4108 & 4108 \\
Weight of soil $(\mathbf{g})$ & 3983 & 4306 & 4445 & 4199 & 4037 \\
Average water content $(\boldsymbol{\%})$ & 13.6 & 16.1 & 18.2 & 20.4 & 21.4 \\
Dry density $\left(\mathbf{g} / \mathbf{c m}^{\mathbf{3}}\right)$ & 1.720 & 1.860 & 1.920 & 1.814 & 1.744 \\
\hline
\end{tabular}

Table 10: Sample 2 Compaction Test

\begin{tabular}{llllll}
\hline Vol. of water added & $\mathbf{3 6 0}$ & $\mathbf{1 2 0}$ & $\mathbf{1 2 0}$ & $\mathbf{1 2 0}$ & $\mathbf{1 2 0}$ \\
\hline Weight of cylinder + soil $\mathbf{( g )}$ & 8256 & 8617 & 9033 & 9106 & 8998 \\
Weight of cylinder $(\mathbf{g})$ & 4172 & 4172 & 4172 & 4172 & 4172 \\
Weight of soil $(\mathbf{g})$ & 4084 & 4445 & 4861 & 4934 & 4826 \\
Average water content $(\boldsymbol{\%})$ & 14.8 & 16.4 & 18.1 & 20.0 & 21.8 \\
Dry density $\left(\mathbf{g} / \mathbf{c m}^{3}\right)$ & 1.652 & 1.771 & 1.907 & 1.903 & 1.832 \\
\hline
\end{tabular}

\subsection{CONCLUSION}

Following the surveys and experiments carried out on the two soil samples obtained from the worst portions of the deteriorated flexible pavement along the Enugu/Port-Harcourt expressway, the submissions are as follows:

i. Presence of clay deposits: all soil tests summarised in table 11 below, provide evidence to assert that there are clay deposits in the underlying layers of the pavement. The high water holding capacity of clay suggests that during rainy season, it will be difficult for rain water to infiltrate quickly into the earth. Clay remains saturated for a good length of time thereby resulting in soil volume fluctuations; cracks and potholes, a corollary. 
ii. Drainage: visual condition survey showed the absence of drainage along the entire route. It may be necessary to identify the critical portions of the alignment that requires drainage.

iii. Axle loading: traffic survey conducted showed significant presence of heavy trucks. The survey results were not presented because it would be necessary to compare it to the traffic survey data used for the design of this highway, to ascertain if the design load has been exceeded.

Table 11: Summary of Tests

\begin{tabular}{lll}
\hline PROPERTIES & SAMPLE 1 & SAMPLE 2 \\
\hline PARTICLE SIZE DISTRIBUTION & A-7-6 Material & A-7-6 Material \\
LIQUID LIMIT & $79.8 \%$ & $85.2 \%$ \\
PLASTIC LIMIT & $43.7 \%$ & $40.6 \%$ \\
PLASTICITY INDEX & $36.1 \%$ & $44.6 \%$ \\
PERMEABILITY TEST & $8.03 \times 10^{-7} \mathrm{~cm} / \mathrm{sec}$ & $8.19 \times 10^{-7} \mathrm{~cm} / \mathrm{sec}$ \\
CBR TEST & $3 \%$ & $3 \%$ \\
COMPACTION TEST & $1.920 \mathrm{~g} / \mathrm{cm}^{3}(\mathrm{MDD})$ & $1.910 \mathrm{~g} / \mathrm{cm}^{3}(\mathrm{MDD})$ \\
& $18.2 \%(\mathrm{OMC})$ & $18.1 \%(\mathrm{OMC})$ \\
\hline
\end{tabular}

\section{REFERENCE}

[1] Sorum, N., Guite, T. and Martina, N. "Pavement Distress: A Case Study," International Journal of Innovative Research in Science, Engineering and Technology, 3(4), (2014), 274-284.

[2] Nega, A., Nikraz, H., Herath, S. and Ghadimi, B. "Distress Identification, Cost Analysis and Pavement," International Journal of Engineering and Technology, 7(4), (2015), 267-275.

[3] Onyelowe, K., Van, D., Igboayaka, C., Orji, F., and Ugwuanyi, H. "Rheology of Mechanical Properties of Soft Soil and Stabilization Protocols in the Developing Countries-Nigeria," Materials Science for Energy Technologies, 2(1), (2019), 814.

[4] Shere, T. K., Worku, A. and Keno, A. "Laboratory Investigations on the Causes of Road Failures Constructed Along Asendabo to Deneba Road Section," International Journal of Engineering Research and Technology, 7(12), (2018), 127-134.

[5] Rather, I. A. and Lateef, E. "Road Pavement Failure of Flexible Pavement from Sanat-Nagar to Pantha-Chowk," International Journal of Advanced Research in Education and Technology, 3(3), (2016), 135-137.

[6] Oyediran, A. T. "Primary Cause of Highway Failure in Southwestern Nigeria and Lasting Solution," Nigeria Society of Engineers (NSE) Technical Transaction, 36(3), (2001), 54-60.

[7] Jegede, G. "Pavement Failure Caused by Soil Physical Properties at a Section of the F209 Highway at Ikole-Ekiti, Southwestern Nigeria," Journal of Biological and Physical Sciences, 1, (2000), 45-54.
[8] Tarawneh, S. and Sarireh, M. "Causes of Cracks and Deterioration of Pavement on Highways in Jordan from Contractors' Perspective," Civil and Environmental Research, 3(10), (2013),16-27.

[9] Abubakar, S. "Bituminous Pavement Failures," Journal of Engineering Research and Application, 6(2), (2016), 94-100.

[10] Adefemi, B. and Ajibola, I. "Flexible Pavement Assessment of Selected Highways in Ifelodun Local Government, Ikirun-Osun, South Western, Nigeria," International Journal of Engineering and Technology, 5(8), (2015), 475484.

[11] Oguara, T. M. "Sustainable Development of High Infrastructure in the Niger Delta Region," Proceedings of the Nigerian Society of Engineers (NSE) Conference, (2002), 4-10.

[12] Tijani, M. A. and Olawale, S. O. A. "Investigation of Flexible Pavement Failure along Ede - Akoda Road, Osun State, Southwestern Nigeria," LAUTECH Journal of Civil and Environmental Studies, 4(1), (2020),1-9.

[13] Adewoye, A. O. and Adegbola, A. A. "Engineering Properties of Foundational Materials of Oyo-Ogbomoso Road in Southwestern Nigeria," Science Focus, 9, (2004), 42-47.

[14] Adeke, P. T., Atoo, A. A. and Orga, S. G. "Assessment of pavement condition index: A case of flexible road pavements on the university of agriculture Makurdi campus," Nigerian Journal of Technology, 38(1), (2019) 15-21.

[15] Ewa, D., Akeke, G. A. and Okoi, D. "Influence of rice husk ash source variability on road subgrade 
properties," Nigerian Journal of Technology, 37(3), (2018), 582-586.

[16] British Standards Institute. BS 1377:1990, Methods of Test for Soils for Civil Engineering Purposes, British Standards Institute, (1990), London.

[17] British Standards Institute. BS 6031:2009, Code of Practice for Earthworks, British Standards Institute, (2009), London.

[18] American Administration for State Highway Officials (AASHTO). Guide for Design of Pavement Structures, AASHTO, (1993), California.
[19] Evirgen, B., Onur, M. I., Tuncan, M. and Tuncan, A. "Determination of the Freezing Effect on Unconfined Compression Strength and Permeability of Saturated Granular Soils," International Journal of GEOMATE, 8(2), (2015), 1283-1287.

[20] Imafidon, D., Ogirigbo, O. R. and J. O. Ehiorobo, "Improvement of Deltaic Lateritic Soil using River Sand and Cement for use as Pavement Construction Material", Nigerian Journal of Technology, 40(2), (2021), 168-176.

[21] Ataev, S. S. Construction Technology, Mir Publishers, (1985), Moscow. 